\title{
Az elökészületi cselekmények büntetendővé nyilvánításának egyes típusairól
}

\section{GÁL Andor ${ }^{1}$}

\begin{abstract}
Az elökészületi cselekmények büntetendővé nyilvánítása voltaképpen a büntetőjogi felelősség kiterjesztésének időbeli síkon megvalósuló formáját jelenti. Jelen tanulmány e cselekmények hazai büntető anyagi jogi szabályozását elsősorban a büntetendőség különböző formáinak ismertetésén keresztül mutatja be. Ezzel összefüggésben büncselekményi példákon keresztül kimutatom, hogy a repressziv büntetőpolitikának köszönhetően mindinkább elterjedőben vannak a párhuzamos kriminalizációt magában foglaló szabályozási megoldások, amelyek az előkészületi büntetendőség túlszabályozását eredményezik.
\end{abstract}

Kulcsszavak: előkészület, felelösség kiterjesztése, kísérlet, sui generis büntetendőség, túlszabályozás

\section{Az előkészületi büntetendőség mint a büntetőjogi felelősség kiterjesztésének egyik formája}

A szándékos bűncselekmény megvalósulásának három szakaszát különíti el egymástól a magyar büntetőjogi szabályozás: előkészület, kísérlet és befejezett bűncselekmény között tesz különbséget. Ezek a stádiumok a törvényi tényálláshoz való viszonyukban különböznek egymástól. Mivel a bűncselekmények törvényi tényállásai befejezett tettesi cselekményt határoznak meg, így a kísérleti szak csupán a törvényi tényállás részbeni megvalósítását feltételezi. Ehhez képest az előkészületi cselekmények a különös részi tényállás keretein kívül esnek, büntetendőségük pedig nem általános jellegű, az a törvény kifejezett rendelkezésén alapul. ${ }^{2}$

Ajogirodalomban általánosan elfogadott meghatározás szerint az előkészület a szándékos bűncselekmény megvalósulásának első stádiumát jelenti, amellyel az elkövető

GÁL Andor dr., PhD, adjunktus, SZTE Állam- és Jogtudományi Kar Bűnügyi Tudományok Intézet, bírósági titkár, Szegedi Ítélőtábla

Andor GÁL dr., PhD, senior lecturer, SZTE Faculty of Law Institute of Criminal Law and Criminal Science, court secretary, Regional Court of Szeged orcid.org/https://orcid.org/0000-0003-2554-8622, andor.gal@juris.u-szeged.hu

2 Vö. Legfelsőbb Bíróság 5/1999. BJE. 
bủncselekményre irányuló szándéka és magatartása a külvilágban megjelenik. ${ }^{3}$ Tekintettel arra, hogy ezek a magatartások a védett jogi tárgyra nézve - a különös részi tényállás keretei közé lépő kísérlethez képest - még csupán távoli veszélyt jelentenek, ezért a Büntető Törvénykönyvről szóló 2012. évi C. törvény (Btk.) kimondja, hogy az ott meghatározott egyes előkészületi cselekmények kizárólag a büntetőkódex kifejezett rendelkezése esetén büntetendőek [11. § (1) bek.].

Az előkészületi cselekmények büntetendővé nyilvánítása voltaképpen a büntetőjogi felelősség kiterjesztésének időbeli síkon megvalósuló formáját jelenti. ${ }^{4}$ A német szakirodalom e megközelítés alatt az úgynevezett „Vorverlagerung” jelenséget érti, amely szerint a törvény egy korábban már kriminalizált cselekmény viszonylatában, a kauzális cselekményfolyamatban időben korábban kifejtett, további magatartást is büntetendővé nyilvánít. ${ }^{5}$ Kriminálpolitikai nézőpontból megállapítható, hogy a „Vorverlagerung" jelenség hazai büntetőjogban való érvényesülése erősödőben van. Mindezt jól mutatja, hogy a - sui generis előkészületi bűncselekményeket ide nem értve - az 1961. évi Btk. (1961. évi V. törvény) és az 1978. évi Btk. (1978. évi IV. törvény) hatálybalépésekor még közel húsz, míg a jelenleg hatályos Btk. több mint hatvan bűncselekmény esetében is büntetni rendeli az előkészületi cselekményeket. Ez a tendencia azon jogalkotói törekvés produktuma, amely az országhatárokon átívelő terrorizmus és szervezett bűnözés jelentette veszéllyel szemben a cselekvésre és tettre kész állam képét kívánja a jogalanyok felé közvetíteni a társadalom megnyugtatása, és biztonságérzete növelése érdekében. ${ }^{6}$

A kifejtettekre figyelemmel az előkészületi cselekmények büntetendőségének rendszere kifejezetten összetetté vált, a korábban létrehozott egyes, osztályozási kategóriák újragondolása indokolt. ${ }^{7}$ Ezáltal lehetőség nyílhat azon cselekmények egymástól való elhatárolására, amelyeket a törvény már büntetni rendel, és amelyek még a büntetendőség körén kívül esnek. E szempontra figyelemmel jelen dolgozat dogmatikai karaktere ellenére a rendészettudomány számára is hasznos eredményekkel szolgálhat, hiszen megvilágíthatja azon cselekmények körét, amelyek esetében már a büntetőjogi jogalkalmazó szervek fellépése szükségesnek mondható. Jelen dolgozat e célkitűzések mentén elemzi a választott témát.

Nagy (2010) 195.; Belovics (2012) 292.

Ezzel párhuzamosan a büntetőjogi felelősség kiterjesztése megfigyelhető tárgyi síkon is, amikor a jogalkotó a büntetőjogi védelem körét további elkövetési tárgyakra is kiterjeszti, de az elkövetési magatartások köre változatlan marad. Sinn (2011) 16.

Ehelyütt példaként a magyar büntetőjogból elegendő a zugírászatot érintő legutóbbi jogszabályi változást hozni: a jogalkotó 2018. január 1-jével a büntetőjogi védelmet kiterjesztette a szabadalmi ügyvivői tevékenységre is. Vö. Btk. 286. §. 5 Sinn (2011) 16.; Puschke (2010) 23-24.

6 Puschke (2010) 16. Hazai szakirodalomban a „szimbolikus büntetőjog” kategóriájához kapcsoltan hasonló értelmezést ad: Nagy (2013) 128.

7 Éppen ezért jelen joghelyzetben már vitathatónak tartom Kónya István azon álláspontját, amely szerint „Az előkészület a Büntető Törvénykönyv Általános Részének olyan intézménye, amely jól kidolgozott, vitathatatlan dogmatikai alapokon nyugszik és a jogalkalmazásban viszonylag kevés problémát okoz." Lásd Kónya (2013) 74. 


\section{A bứncselekmény elökészületi és kísérleti stádiumának elhatárolására vonatkozó elméletek}

Az előkészületi cselekmények fogalma a büntetőtörvénykönyv általános részéről szóló 1950. évi II. törvény hatálybalépéséig ${ }^{8}$ törvényi meghatározással nem rendelkezett. ${ }^{9}$ Erre figyelemmel az azt megelőző jogirodalom érdeklődésének középpontjában elsősorban e cselekmények definiálása és e definíciónak megfelelő egyes magatartások kísérleti stádiumtól való elhatárolása állt. ${ }^{10}$ Ezt követően a vizsgálódások viszonyítási pontját szükségképpen már a törvényi fogalommeghatározás jelentette.

A törvényi definíció megalkotása óta pedig a büntetőjogi szabályozás - a fentiekben megjelölt kriminálpolitikai célok elérése érdekében - folyamatos változáson esett át, amely odáig vezetett, hogy jelen joghelyzetben az előkészületi magatartások büntetendővé nyilvánításának már különböző formái léteznek, amelyeknek egymáshoz való szabályozási viszonya álláspontom szerint ténylegesen csak akkor válhat megérthetővé, ha kiindulópontként az előkészület-kísérlet fogalompár elhatárolásának hazai büntetőjogban való felfogása tisztázásra kerül.

Erre figyelemmel a következőkben az előkészületi és a kísérleti stádium megkülönböztetésére a büntetőjog-tudomány által kidolgozott egyes elméleteket - a magyar szabályozástól elvonatkoztatva - prezentálom annak érdekében, hogy a főszabály szerint büntetlennek minősülő előkészületi cselekmények a büntetőjogi felelősséget már megalapozó kísérleti stádiumtól elkülöníthetővé váljanak. Az egyes teóriák különböző jellemzőinek említése elvétve már megjelenik a korábbi hazai jogirodalomban, ${ }^{11}$ rendszerezett, egymással összevetett bemutatásukra kifejezetten azonban nem került sor. ${ }^{12}$

\section{Objektív elméletek}

Az objektív teóriák középpontjában eredendően azon gondolat áll, hogy a büntetőjogi beavatkozás akkor válik szükségessé, ha az oltalmazott jogi tárgy konkrét veszélyeztetettsége a cselekménnyel összefüggésben fennáll. ${ }^{13}$ Az objektív megközelítés alapján pedig a jogi tárgy veszélyeztetettsége körében az orientációs pontot maga a törvényi tényállás, még pontosabban annak közelsége jelenti. Roxin elismeri, hogy a „tényállás közelsége” („Tatbestandsnähe”) ténylegesen nem egzakt kategória, hanem egy objektív alapon nyugvó, olyan zsinórmérték, amiből a konkrét cselekmény minősítése levezethetővé válik. ${ }^{14}$

\footnotetext{
Hatályos 1951. január 1-jétől.

Az első előkészületi legáldefinícióra lásd Btá. 19. § (1) bek.

10 Erre lásd például Fayer (1895) 195-197.; Bursics (1937) 62-63.

11 Így foglalkozott az előkészület-kísérlet fogalompár közötti elhatárolás elméleti megalapozásával az elmúlt századforduló szakirodalmában Wlassics (1887) 96-112.; Wlassics (1914) 317-325.; Heil (1911) 39-45.; Heller (1931) 257-259.

12 Ahogy Nagy Ferenc is felhívja a figyelmet a téma elméleti kidolgozatlanságára: „Az előkészületről elmondható, hogy ezzel kapcsolatban a mai napig gyakorlatilag alig rendelkezünk specifikus irodalommal." Nagy (2008) 769.

13 Eser-Bosch (2014) 417.

$14 \operatorname{Roxin}(2003) 362$.
} 


\section{Formál-objektív teória}

E megközelítés a kísérlet fogalmi körét kifejezetten restriktíven értelmezi azáltal, hogy annak kezdetét a tényállásszerú elkövetési magatartás megkezdéséhez kapcsolja. ${ }^{15} \mathrm{~Eb}-$ ből következően az előkészület és a kísérlet elhatárolása voltaképpen az érintett bűncselekményi tényálláshoz kapcsolódó szubszumciós vizsgálat alapján oldható meg: ha a történeti tényállásban foglalt cselekmény részben a bűncselekményi tényállás körébe vonható, akkor az adott büncselekmény kísérleti stádiumban valósul meg. ${ }^{16}$

Roxin és az Eser-Bosch szerzőpáros szerint e szemlélet érdeme garanciális szempontból az, hogy a kísérletet a kötelezően alkalmazandó törvényi tényállásba inkorporálja, így az elhatárolás alapját maga a norma szövege jelenti. ${ }^{17} \mathrm{~A}$ formál-objektív koncepció hátrányaként említhető ugyanakkor, hogy kizárólag olyan büncselekményi tényállások esetében alkalmazható, amelyek elkövetési magatartása pontosan körülírt, így a részbeni tényállás-megvalósítás kérdésében egyértelmúen lehet állást foglalni. ${ }^{18}$ Ebből fakadóan a teória nem szolgáltat tényleges elhatárolási alapot az olyan akár tetlegességgel, akár mulasztással megvalósítható bűncselekmények többsége esetében, ahol az elkövetési magatartás nem konkrétan meghatározott. ${ }^{19}$ Így az úgynevezett nyitott törvényi tényállások vagy a keretdiszpozíciós norma által meghatározott szabályok megszegésében álló bűncselekmények esetében ezen elmélet nem feltétlenül igazít el a stádiumtani minősítés kérdésében. Szintén e megközelítés hátrányos hatásaként említi továbbá a francia és német szakirodalom azon körülményt, amely szerint az elhatárolás tényálláshoz kapcsolása a kísérlet fogalmi körét jogtárgyvédelmi szempontból túlzottan leszúkíti, ami társadalomra egyébként veszélyes cselekmények büntetlenül hagyását eredményezheti. ${ }^{20}$

\section{Materiál-objektív teória}

A német jogirodalomban az úgynevezett materiál-objektív elhatárolási elmélet megalapozása Reinhard Frank nevéhez köthető. ${ }^{21} \mathrm{~A}$ teória lényege szerint a cselekmény akkor juthat a kísérlet szakaszába, ha az az általános és természetes életszemlélet szerint már az adott bűncselekmény által oltalmazott jogi tárgyra nézve konkrét és tényleges veszélyt jelent. Ennek következtében olyan cselekmények is kísérletet valósíthatnak meg, amelyek még részben sem tekinthetők tényállásszerünek, a jogi tárgyra nézve azonban már konkrét fenyegetést jelentenek. Így Gropp példája szerint nem csupán a lőfegyver emberölési szándékkal történő elsütése, hanem a fegyver ravaszának ilyen szándékkal történő megérintése is már kísérletként értékelendő.

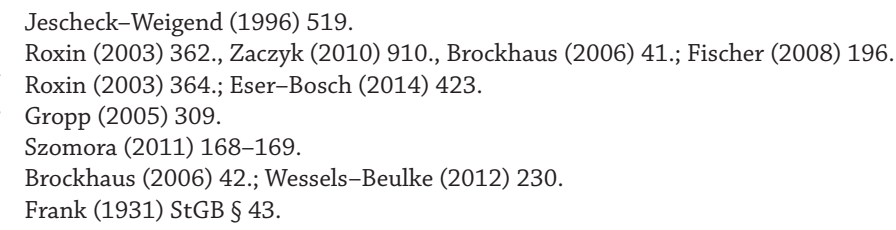




\section{Félreérthetetlenségi elmélet}

Ezen olasz jogtudomány által kidolgozott, de a francia szakirodalom által is ismert megközelítés alapján kísérleti stádiumba akkor lép a cselekmény, amikor a külvilágban megjelenő magatartásból egyértelműen és kétséget kizáróan a büncselekmény elkövetésére vonatkozó szándék fennálltára lehet következtetést vonni. ${ }^{22}$ Ebből adódóan, amennyiben a cselekmény az objektív körülmények alapján megcáfolhatatlanul bűncselekmény elkövetésére irányul, a szándékot a tárgyi tényezők alapján vélelmezni kell, és az érintett deliktum kísérlete megállapításának van helye. Így a francia szakirodalom által szolgáltatott példa szerint elegendő a lopás kísérletének megállapításához már az, ha az elkövető a gépjármúvet feltörve, annak utasterébe jut. ${ }^{23}$

\section{Szubjektív elmélet}

A szubjektív elhatárolási koncepció lényege szerint a búncselekmények egyes stádiumai egymás közötti viszonyának meghatározása során csak az elkövető tudattartalma jelenthet eligazodási pontot, lévén a büntetőjogi felelősség alapját is a bűnösség képezi (bünösségen alapuló felelősség elve). A teória szerint a szándék külvilágban való megjelenése már az adott cselekmény büntetendőségének alapját jelenti, a törvényi tényállás pedig a cselekmény irányultságára vonatkozóan (a szándék konkretizálása során) nyújt eligazodási pontot. Ebből fakadóan a kísérlet és előkészület közötti éles elhatárolás is szükségtelen, mivel azon cselekmények, amelyek már az adott bű́ncselekmény elkövetésére vonatkozó szándék megnyilvánulásaként foghatók fel, kísérletként értendők. Azok a magatartások, amelyek bűnösség síkján e szintet nem érik el, büntetőjogilag irreleváns cselekményeknek minősíthetők, amelyek a szubjektív felfogás szerint büntetőjogi felelősséget még nem alapozhatnak meg. Konklúzióként állapítható meg, hogy a tisztán szubjektív felfogás elfogadása a kísérleti büntetendőség hatókörét összességében kiszélesíti. ${ }^{24}$

\section{Konklúziók az uralkodó magyar állásponttal összefüggésben}

Ahogy a fentiekben már utaltam rá, a magyar büntetőjogi szabályozás stádiumtani szempontból kifejezetten az objektivista megközelítés talaján áll, amelyet a büntetőkódex azáltal juttat kifejezésre, hogy a szándékos büncselekmény-kísérletének bünte-

\footnotetext{
22 A koncepció kidolgozója a francia büntetőjogban a Roger Merle - André Vitu szerzőpáros. Lásd Brockhaus (2006) 43-45.

23 Brockhaus (2006) 44

24 Wessels-Beulke (2012) 230.
} 
tendőségét hagyományosan az elkövetés megkezdéséhez kapcsolja. ${ }^{25} \mathrm{E}$ következtetést a hazai szakirodalomban Hollán Miklós ${ }^{26}$ és Szomora Zsolt ${ }^{27}$ is levonja azáltal, hogy a hatályos szabályozást a formál-objektív elmélettel hozza összefüggésbe.

Így az elkövetés megkezdéséhez legalább a különös részi törvényi diszpozíció objektív tényállásának - közelebbről a bűncselekmény elkövetési magatartásnak vagy elkövetési módjának ${ }^{28}$ - részbeni megvalósítása szükséges. Ez az értelmezés világos határ húzására alkalmas azon diszpozíciók esetében, ahol az elkövetési magatartás egzakt formában meghatározott. Ahogy korábban említettem, az úgynevezett nyitott törvényi tényállások (például emberölés, testi sértés) vagy a keretdiszpozíciós norma által meghatározott szabályok megszegésében álló bűncselekmények (például hútlen kezelés, szerzői vagy szerzői joghoz kapcsolódó jogok megsértése) esetében a formál-objektív teória nem feltétlenül igazít el, mivel az elkövetési magatartás részbeni megvalósulására vonatkozó állásfoglalásában való döntést a jogi tárgy elleni támadás mértéke befolyásolhatja.

Összegzésképpen elmondható, hogy a magyar büntetőjogban uralkodó formálobjektív megközelítés alapján a befejezetlen bűncselekmény stádiumtani minősítését alapvetően a különös részi törvényi tényállás ismérvei határozzák meg. Abban az esetben, ha a tényállásszerkesztés sajátosságai okán az elkövetés megkezdésének értelmezése nehézséget okoz, a magyar büntetőjog kiegészítő jelleggel a materiál-objektív teóriát is értékesíti azáltal, hogy a kísérlet-előkészület elhatárolása a védett jogi tárgy tényleges veszélyeztetettségén alapul.

\section{Az előkészület büntetendőségének egyes formáiról}

\section{Teljes körü elökészületi büntetendőség}

Az előkészület kriminalizálására vonatkozó jogalkotói szándék többféle módon jelenik meg a hatályos büntetőkódexben. A törvény büntetendővé nyilváníthatja valamennyi előkészületi magatartást oly módon, hogy az „előkészület” szó használatával visszautal az általános részi diszpozícióra. Ebben az esetben a cselekmény büntetendőségét a Btk. általános és különös részében foglalt rendelkezések voltaképpen együttesen alapozzák meg: a Btk. 11. § (1) bekezdésében meghatározott egyes elkövetési magatartások ugyanis ténylegesen a különös részi tényálláshoz kapcsolódnak, és csak arra tekintettel válhatnak értelmezhetővé.

\footnotetext{
25 Így a kísérleti stádium megnyílásával összefüggésben a Csemegi-kódex (1878. évi V. tc. a magyar büntetőtörvénykönyv a büntettekről és vétségekről 65. §), a Btá. (17. §) és az 1961. évi Btk. (1961. évi V. tv. a Magyar Népköztársaság Büntető Törvénykönyvéről 9. §) a „véghezvitel megkezdéséről” rendelkezett; míg az 1978. évi Btk. (1978. évi IV. törvény a Büntető Törvénykönyvről 16. §) és a hatályos büntetőkódex (2012. évi C. tv. a Büntető Törvénykönyvről 10. §) az „elkövetés megkezdéséről” szól.

26 Hollán (2013) 191.

27 Szomora (2011) 158., 164.

28 Hollán szerint az elkövetési mód kifejtése csak akkor hoz létre kísérletet, ha annak megvalósítására a szándékolt elkövetési magatartással szoros térbeli és időbeli kapcsolatban kerül sor. Hollán (2013) 191.
} 
Ahogy korábban említettem, erre több mint hatvan bủncselekmény esetében is találunk példát a hatályos büntető anyagi jogban, legutóbb például - 2018. január 1-jei hatállyal - az egészségügyi termék hamisítása bű́ncselekményére irányuló előkészületet nyilvánította büntetendővé a jogalkotó [Btk. 186. § (4a) bek.]. Ez a szabályozási modell a Btá. óta alkalmazott a magyar büntetőjogban, és jelenleg (még) ez tekinthető általánosan érvényesülőnek.

\section{Nem teljes körú elökészületi büntetendöség}

Lehetséges továbbá az is, hogy a jogalkotó csak meghatározott előkészületi cselekményt von be a büntetőjogi szabályozás körébe, ekkor a többi, a Btk. 11. § (1) bekezdésében meghatározott magatartás tanúsítása argumentum a contrario nem keletkeztethet büntetőjogi felelősséget. Az ilyen típusú előkészületi alakzat a befejezett bűncselekményhez kapcsolódó úgynevezett valódi elökészület, ${ }^{29}$ vagyis nem sui generis deliktum, amelytől az önkéntes visszalépésre van törvényes lehetőség. ${ }^{30}$ Hollán Miklós szerint mindez a logikai értelmezésből következik, mivel sui generis bűncselekmények közé besorolása által kizárnánk az elkövetőt az előkészülettől való önkéntes visszalépésre vonatkozó büntethetőséget megszüntető ok [Btk. 11. § (2) bek.] alkalmazásának lehetőségéből csak azért, mert a törvény egy előkészületi magatartást rendel büntetni, jóllehet azoknál a deliktumoknál, ahol valamennyi előkészületi magatartás büntetendő, erre van törvényes lehetőség. Ezen álláspont dogmatikai helyességét igazolja azon további érv is, hogyha ezeket a tényállásokat sui generisnek fogadnánk el, kísérletük nem lenne fogalmilag kizárt, miáltal a kísérlet körén belül további (materiális értelemben) ${ }^{31}$ előkészületi cselekmények is megalapozhatnák a büntetőjogi felelősséget, ami a jogalkotói szándékkal nyilvánvalóan ellentétes, hiszen a törvény kifejezetten csupán egy előkészületi magatartást pönalizál. Erre a kategóriára példaként hozható a pénzmosás [Btk. 399. § (5) bek.] vagy az üzletszerű kerítés [Btk. 200. § (6) bek.] elkövetésében való megállapodás vagy a szexuális erőszakhoz szükséges vagy azt könnyítő feltételek biztosítása [Btk. 197. § (5) bek.].

29 Hollán (2006); Tokaji Géza szerint a valódi előkészületi jelleg abból is adódik, hogy az ilyen bűncselekmény jogtárgyveszélyeztetô volta kizárólag a befejezett búncselekményhez füződő viszonyából és nem pedig önálló szabályozásából fakad. Tokaji (1984) 334.

30 Korábban ettől eltérő álláspontra helyezkedett Varga Zoltán akkor, amikor a pénzmosás elkövetésében megállapodást befejezett büncselekménynek tekintette, az újabb (2009-es), még a korábbi Btk.-hoz írt kommentárban azonban már - megváltoztatva álláspontját - a tényállást valóságos előkészületként fogja fel. Varga (2004) 1194.; Varga (2009) 1289.

31 A materiális értelemben vett előkészületet elismerő - a recens magyar jogirodalomban kevéssé ismert - teória egy dogmatikai kategória, amely az előkészületfogalmat tágítja akképpen, hogy nemcsak a Btk. 11. § (1) bekezdésében meghatározott cselekmények minősülnek a büntetőjog-tudományban előkészületnek, hanem azok a különös részi tényállások is, amelyek tényállási elemeik tartalmánál fogva egy másik deliktum előkészületeként foghatóak fel. A Karsai-Szomora szerzőpáros ismerteti - a korábbi Btk. kapcsán, de a hatályos kódex alapján is helytálló - azon példát, amely a közokirat-hamisítás két alakzatát [Btk. 342. §a) és b) pontok] helyezi el ilyen viszonyrendszerben. Karsai-Szomora (2011) 316. 


\section{Előkészületi büntetendőség befejezett büncselekményként}

\section{Sui generis elökészületi büntetendöség}

Az előkészületi büntetendőség törvényi kifejezése történhet úgy is, hogy a büntetőtörvény a kriminalizálni kívánt előkészületi cselekményt egy önálló büncselekmény elkövetési magatartásaként, sui generis módon határozza meg. Ennek az esetkörnek eklatáns példája lehet az információs rendszer védelmét biztosító technikai intézkedés kijátszása (Btk. 424. §) vagy a hamis tanúzásra felhívás (Btk. 276. §) is.

E büntetendőségi forma büntetőjog-dogmatikai sajátosságaira külön is érdemes kitérni. A büntetőjogi jogszabálytan egyik alapvető tételének számít az, hogy a jogalkotó a büntetőjogi felelősséget megalapozó különös részi tényállásokat befejezett, önálló tettesi alakzatban határozza meg. Abban az esetben, ha ezek a diszpozíciók elkövetési magatartásként olyan cselekményeket jelölnek meg, amelyek a Btk. Általános Része alapján más deliktumot érintően - adott esetben további törvényi feltételek teljesülése esetén ${ }^{32}$ - egyébként is büntetendőek lennének (például előkészület, felbujtás, bűnsegély) ${ }^{33}$ akkor sui generis búncselekményi tényállásról szólunk, hiszen a büntetőjogi felelősséget kifejezetten már nem az általános részi diszpozíció, hanem ez a különös részi rendelkezés mint önálló deliktum alapozza meg. Az előkészületi magatartás befejezett ${ }^{34}$ bűncselekményként történő szabályozása az alábbi jogkövetkezményeket eredményezi:

1. Az előkészülettől való önkéntes visszalépés [Btk. 11. § (2) bek.] mint büntethetőséget megszüntető egyéb ok nem alkalmazható.

2. A büncselekmény (a valódi előkészülettel ellentétben) kísérleti stádiumban is megvalósulhat. ${ }^{35}$

3. A büncselekményhez kapcsolódhat felbujtás vagy búnsegély.

Nem nehéz belátni, hogy az előkészület ilyen formában történő kriminalizálása az elkövetőre nézve in abstracto hátrányosabb, jóllehet ezt a képet árnyalhatják egyéb tényezők. Ilyen lehet például büntethetőséget megszüntető ok társítása a sui generis deliktumhoz [például: Btk. 424. § (2) bek.], valamint kísérlet esetén a befejezettség elmaradását a bíróság enyhítő körülményként is értékelheti a büntetéskiszabás körében. ${ }^{36}$

\footnotetext{
32 Ilyen további feltétel alatt értem például az előkészület viszonylatában azt, hogy a másik büncselekmény előkészületét a törvény büntetni rendelje.

33 Kivételesen sui generis kísérleti bűncselekményt is szabályoz a Btk., erre a kategóriára Hollán Miklós az alkotmányos rend erőszakos megváltoztatása [Btk. 254. § (1) bek.], illetve a züllött életmódra rábírni törekvéssel elkövetett kiskorú veszélyeztetése tényállását [Btk. 208. § (2) bek.] hozza példaként. Hollán (2013) 187.

34 Ez az ismérv a búncselekmény sui generis jellegéből már magától értetődően következik, így egymás mellett történő említésük nem szükséges. Befejezett, sui generis bűncselekmény kifejezésre lásd Balogh (2007) 72.

35 Megjegyezhető, hogy a korábbi szakirodalomban olvasható ezzel ellentétes, ám már meghaladottnak tekinthető olyan álláspont, amely a kísérleti megvalósulást befejezett bủncselekményként szabályozott előkészület esetében kizárta. Bursics (1937) 64.

36 Lásd Kúria 56. BK vélemény III. 1. pont.
} 


\section{Kvázi sui generis elökészületi büntetendöség}

Tovább tágítva a dogmatikai kategóriát, megkülönböztethetők még kvázi sui generis előkészületi tényállások is, ${ }^{37}$ amelyeket Nagy Ferenc rendszeridegen, besorolhatatlan előkészületi bủncselekmények között tart számon. ${ }^{38}$ Alapvető ismérvük, hogy a jogalkotó olyan előkészületi jellegű magatartást rendel önálló deliktum keretében büntetni, amely egyébként tartalmilag az előkészület legáldefiníciójának valamely tartalmi elem (például a szubjektív oldalon a célzat) hiánya miatt nem feleltethető meg. Példaként erre a speciális kategóriára a pénzhamisítás elősegítése (Btk. 390. §) vagy a készpénzhelyettesítő fizetési eszközzel visszaélés elősegítése (Btk. 394. §) szolgálhat.

\section{A párhuzamos kriminalizáció mint a sui generis büntetendőség expanziójának következménye}

A fentiekben rögzítettekre figyelemmel az a hipotézis állítható fel, hogy a sui generis előkészületi bűncselekmények megalkotása olyan magatartások kriminalizálása érdekében történik, amelyek az alapbüncselekmény elókészületének büntetlensége (vagy más egyéb sui generis büncselekmény hiánya) folytán egyébként nem lennének büntetendöek, és feltehetően a materiálisan előkészületi jellegü cselekmény fokozott társadalomra veszélyességére tekintette ${ }^{39}$ a jogalkotó nem elégszik meg - a fentiekben kifejtettek alapján in abstracto az elkövetőre nézve kedvezőbb - valódi előkészületi diszpozícióban történő szabályozásukkal. Ezt a konjunktív szempontokon alapuló feltevést alátámaszthatja a hamis tanúzásra felhívás tényállása (Btk. 276. §), amelynek hiányában a felhívás - a hamis tanúzás (Btk. 272-275. §) előkészületének büntetlensége folytán - büntetőjogi szabályozás nélkül maradna, jóllehet a jogi tárgy (igazságszolgáltatás rendje) nem vitathatóan széles körü büntetőjogi védelemre igényt tartó társadalmi érdek.

Megcáfolni látszik újabban e feltevés helytállóságát ugyanakkor több bűncselekményi tényállás is. A teljesség igénye nélkül a következőkben olyan tényállás-kollíziókat mutatok be, amelyek az előkészületi büntetendőség túlszabályozottá válását támasztják alá.

\footnotetext{
Ennek a kategóriának az elkülönítése korábban megjelenik Hollán Miklósnál és az Ambrus-Deák szerzőpárosnál is. Hollán (2013) 187.; Ambrus-Deák (2011) 94.

38 Nagy (2010) 195.

39 Váradi Erika a sui generis előkészületi bűncselekmények megalkotásának indokát szintén egyes társadalmi érdekek jelentős mértékű veszélyeztetésében látja, továbbá elképzelhetőnek tartja (például a tizennegyedik életévét be nem töltött személynek a szexuális cselekményre történő felhívása kapcsán), hogy egyes előkészületi magatartások a célcselekmény jogi tárgyán túli további jogtárgysérelem megvalósulását is magukban hordozhatják. Váradi (2012) $234-235$. A sui generis tényállások megalkotásának indokát a jogi tárgy súlyos fokú veszélyeztetésében látja Tokaji (1984) 333.
} 


\section{Kábítószer-birtoklás elökészülete - kábítószer készítésének elösegítése}

A kábítószer termesztése vagy előállítása céljából, az ahhoz szükséges anyag, berendezés vagy felszerelés készítését, megszerzését, az országba történő behozatalát, onnan történő kivitelét vagy azon átszállítását, illetve átadását, ugyanis annak ellenére önálló bűncselekmény (kábítószer készítésének elősegítése) formájában pönalizálja a Btk. 182. § (1) bek. a) pontja, hogy a kábítószer termesztésére, előallítására irányuló előkészület egyébként a kábítószer birtoklása keretében [Btk. 178. § (4) bek.] büntetendô cselekményt képez.$^{40} \mathrm{Az}$ önálló deliktum megalkotásának indokát nemzetközi jogi vagy uniós jogalkotási kötelezettség szolgáltathatná, hiszen maga a miniszteri indokolás is erre hivatkozik, ${ }^{41}$ azonban a hazánkra kötelező instrumentumok által támasztott követelményeket ${ }^{42}$ már a kábítószer-birtoklás előkészülete [Btk. 178. § (4) bek.] messzemenőkig kielégíti, tekintettel arra, hogy a magyar törvényhozó az előkészület generális fogalmát rendkívül széleskörúen határozta meg, ${ }^{43}$ amely valamennyi, a Btk. 182. § (1) bek. a) pontjában meghatározott célzatos magatartást lefed.

A kifejtettek fényében megállapítható, hogy a jogalkotó egy alaki halmazati kollíziót kreálva „túlszabályozta” a kérdést, amelyből ugyanazon cselekmény társadalomra veszélyességének eltérő jogalkotói megítélésére lehet következtetést vonni, figyelemmel arra, hogy az említett két deliktum büntetési tétele egyébként eltérő. A „túlszabályozás" további ékes bizonyítéka az is, hogy a jogalkotó - Btk.-ban egyébként egyedülálló módon - még a sui generis előkészületi büncselekmény előkészületét is büntetni rendelte [Btk. 182. § (4) bek.]. Mivel a kábítószer-készítés elősegítésének alaptényállása [Btk. 182. § (1) bek.] a kábítószer előállítására, termesztésére irányulóan célzatos büncselekmény, az ahhoz kapcsolódó, szintén célzatos előkészületi magatartás elkövetőjének tudata - ha közvetetten is - átfogja a kábítószer termesztéséhez, előállításához szükséges, vagy azt könnyítő feltételek biztosítását, ami alapján cselekménye szintén a kábítószer birtoklása előkészületeként [Btk. 178. § (4) bek.] minősülhet. A miniszteri indokolás az előkészület kriminalizálását azzal magyarázza, hogy vannak olyan anyagok, amelyekre nézve (egy évre vetítve bizonyos határértékig) az uniós joganyag mentességet ad az engedélyeztetés alól, és ezzel gyakran visszaélnek, ami indokát képezi a büntetőjogi eszközökkel való fellépésnek. ${ }^{44} \mathrm{Az}$ indokolás ratio legisre vonatkozó okfejtése nem igazán érthető, hiszen a kábítószer eloállításához szükséges anyag célzatos

40 Az elhatárolási kérdés bonyolultságát tovább növeli, hogy a kábítószer készítésének elősegítése vegyes jellegű sui generis bűncselekménynek tekinthető, hiszen előkészületi-bűnsegédi karakterủ magatartásokat rendel büntetni, így a tényállás kollidál a kábítószer birtoklása anyagi eszközök szolgáltatását kriminalizáló sui generis büncselekményi alakzatával [Btk. 178. § (3) bek.] is.

41 Lásd a Büntető Törvénykönyvről szóló 2012. évi C. törvény 182-183. §-hoz füzött miniszteri indokolást.

42 A követelményekre lásd 1988. évi bécsi egyezmény, 3. cikk. Kihirdette: 1998. évi L. törvény az Egyesült Nemzetek Szervezete keretében a kábítószerek és pszichotróp anyagok tiltott forgalmazása elleni, 1988. december 20-án, Bécsben kelt egyezmény kihirdetéséről.; a tanács 2004. október 25-i 2004/575/IB Kerethatározata a tiltott kábítószerkereskedelem területén a bủncselekmények tényállási elemeire és a büntetésekre vonatkozó minimumszabályok megállapításáról 2. cikk (1) bek.

43 A Btk. 11. § (1) bek. 3. fordulata szerint előkészületet valósít meg, „aki a bűncselekmény elkövetése céljából az ehhez szükséges vagy ezt könnyítő feltételeket biztosítja”.

44 Vö. Büntető Törvénykönyvről szóló 2012. évi C. törvény 182-183. §-hoz füzött miniszteri indokolással. 
megszerzésével a bűncselekmény tényállásszerű, és ha mindez az uniós jog adta mentességek megszegésével történik - absztrakt jogszabályi engedély hiányában - a cselekmény, nemcsak diszpozíciószerű, hanem jogellenes is. A bűncselekmények találkozásából adódó egység-többségtani probléma egyébként a látszólagos halmazatra vonatkozó elvek igénybevételével oldható meg, közelebbről a szubszidiaritási klauzula és a specialitás szabálya segítségével. Ez alapján a kábítószer birtoklása előkészülete a Btk. 182. §-ban foglalt egyes elkövetési magatartások és elkövetési tárgyak specialitása folytán csak látszólagos alaki halmazatban áll a sui generis deliktummal, továbbá az átadás fordulatának vonatkozásában a kábítószer birtoklásához történő anyagi eszközök szolgáltatásához képest a szubszidiaritási klauzula alapján csak akkor lép háttérbe, ha az 5 évi szabadságvesztésnél súlyosabban büntetendő.

\section{Kóros szenvedélykeltés - kiskorú veszélyeztetése}

A kiinduló premisszát megdönteni látszó másik bűncselekményi példaként a kóros szenvedélykeltés második vétségi változata [Btk. 181. § (1) bek. b) pont] merülhet fel. A tényállás büntetni rendeli azt a tizennyolcadik életévét betöltött elkövetőt, aki a tizennyolcadik életévét be nem töltött személyt kábítószer fogyasztására törekszik rábírni. Utóbbi magatartás a joggyakorlat ${ }^{45}$ és a jogirodalom ${ }^{46}$ által is egységesen felhívásként értékelendő cselekmény, így ez a deliktum a sui generis előkészületi tényállások közé sorolandó be. Mivel a kábítószer fogyasztására irányuló előkészület nem bűncselekmény, a jogi tárgy (tizennyolcadik életévüket be nem töltött személyek egészségének védelméhez fűződő társadalmi érdek) jelentőségére tekintettel kriminálpolitikai szempontból indokoltnak tűnik a büntetőjogi szabályozás - sui generis tényállás formájában történő - kiterjesztése ezen előkészületi cselekményre. A probléma ott jelentkezik, hogy ezt a magatartást egy másik sui generis előkészületi tényállás már lefedi, mégpedig a kiskorú veszélyeztetésének második alakzata. ${ }^{47} \mathrm{~A}$ Btk. 208. § (2) bek. a) pontja szerint ugyanis búntettet követ el az a tizennyolcadik életévét betöltött személy, aki tizennyolcadik életévét be nem töltött személyt bűncselekmény elkövetésére rábírni törekszik. Az új Btk. hatálybalépésével a kábítószer fogyasztása ismételten büncselekményt képez, ${ }^{48}$ így a tizennyolcadik életévét be nem töltött személy erre történő felhívása maradéktalanul kimeríti a kiskorú veszélyeztetésének tényállását, amely egyébként súlyosabb szankcióval - egy évtől öt évig terjedő szabadságvesztéssel - fenyegetett bűncselekmény, mint a kóros szenvedélykeltés vétségi alakzata. Ezek alapján a Btk. 182. § (1) bek. b) pontjában szabályozott tényállás megalkotásának indoka

\footnotetext{
45 A hamis tanúzásra felhívás kapcsán kialakult judikatúrára lásd BH 1983. 389.

46 Belovics (2012b) 134.; Vida (2013) 101.

47 Hollán ezt a bűncselekményt sui generis kísérletnek tekinti, mivel a rábírni törekvés a másik elkövetési magatartáshoz, a rábíráshoz képest (sui generis) kísérlet. Hollán (2013) 194. A megállapítás dogmatikailag helyes, de esetünkben az összevetés egy másik bűncselekménnyel történik, így indokolt fenntartni a sui generis elökészületi büncselekménykénti besorolást.

48 Vö. Btk. 178. § (6) bek.
} 
nehezen érthető, a kérdés megoldásában a történeti értelmezés sem nyújt segítséget, mivel a miniszteri indokolás csak annyit jegyez meg, hogy az eredménytelen felbujtás kriminalizálását a szabályozás egységessé tétele (tudniillik eddig csak a kábítószeren kívüli egyéb kábító hatású anyagok esetében volt a rábírni törekvés büntetendő) indokolta. ${ }^{49}$ Feltehetően arról lehet szó, hogy a jogalkotó figyelmét elkerülte az, hogy a kábítószer fogyasztása kriminalizálásával, ugyan más bűncselekmény keretei között, de adott a büntetőjogi védelem. Ennek azonban újabb alaki halmazati anomália lett a következménye, amit ismételten a specialitás elvével lehet feloldani. A kóros szenvedélykeltés mint - a Btk. más fejezetében kodifikált privilegizált tényállás - előtérbe lép a kiskorú veszélyeztetéséhez képest, ugyanis a felhívás pontosan meghatározott deliktumra [Btk. 178. § (6) bek.] irányul, míg ez a kiskorú veszélyeztetésénél nincs konkretizálva. ${ }^{50} \mathrm{~A}$ büntetési tételek összevetése alapján megállapítható tehát, hogy ugyanazon életbeli cselekmény társadalomra veszélyességének eltérő jogalkotói megítélésével találkozunk e tényállás-kollízió esetében is.

\section{Terrorizmus finanszírozása - terrorcselekmény sui generis elökészülete}

Végezetül a terrorizmus finanszírozása tényállását ${ }^{51}$ (Btk. 318-318/B. §) érintő legújabb jogszabályi változások ${ }^{52}$ újabb példát szolgáltatnak az általam jelzett szabályozási jelenségre. A Btk. 318. § (1) bek. a) pontjában meghatározott bủncselekmény a terrorcselekmény feltételeinek biztosításához anyagi eszköz szolgáltatását vagy gyüjtését rendeli büntetni. E diszpozíció voltaképpen egy sui generis előkészületi bủncselekményhez [Btk. 315. § (1) bek.] kapcsolódó sui generis részesi (bűnsegédi) magatartást rendel büntetni. Ahogy a fentiekben már kiemeltem, a sui generis előkészületi büncselekmény egyik dogmatikai jellemzője az, hogy esetében részesként a tényállásmegvalósítás lehetséges. Ebből fakadóan az állam jogtárgyvédelmi, illetve uniós jogi kötelezettségének tulajdonképpen már a terrorcselekmény előkészületének sui generis szabályozásával eleget tesz.

\section{Konklúziók}

Megállapítható, hogy a „Vorverlagerung” jelenségnek a magyar büntetőjogban való dominánssá válásával, az előkészületi rendelkezések rendszerint csupán egyfajta szimbolikus politikai, és nem feltétlenül tényleges jogtárgyvédelmi célt szolgálnak. Ezzel összhangban a büntetendő előkészületi cselekmények száma kiugróan megnövekedett, ezen belül is meghatározó szabályozási eszközzé a sui generis tényállások váltak.

\footnotetext{
Vö. Büntető Törvénykönyvről szóló 2012. évi C. törvény 181 §-hoz füzött miniszteri indokolással.

Ugyanezen álláspontra lásd Vida (2013) 67.

1 E tényállás részletes elemzéséhez lásd Gál (2012); Gál (2013); Dávid-Gál (2015); Gál (2017).

52 2017. évi XXXIX. törvény az európai uniós és a nemzetközi bűnügyi együttműködést szabályozó törvények, és ehhez kapcsolódóan más törvények jogharmonizációs célú módosításáról 62. § (1)-(2) bek.
} 
A szabályozási struktúra érthetővé tétele érdekében felvázoltam az előkészület és kísérlet elhatárolására vonatkozó elméleteket, amely lehetővé tette a hazai szabályozási környezet karakterisztikájának meghatározását is.

Dolgozatomban külön kitértem a sui generis bűncselekményként történő szabályozása kapcsán felmerülő dogmatikai kérdésekre, emellett egyfajta problémafelvetésként tényállás-kollíziókat prezentáltam annak érdekében, hogy az előkészületi cselekmények túlszabályozottságának kérdésére rávilágíthassak. Példákon keresztül arra kívántam rámutatni, hogy az előkészület sui generis módon történő kriminalizálása a hatályos büntetőjogban több esetben nem következetes, amely a büntetőjogi szabályozást kazuisztikussá teszi azáltal, hogy tényállás-kollíziók létrejöttét eredményezi. Megjegyezhető, hogy ezen elhatárolási kérdések az egyes látszólagos halmazati kategóriák felhasználásával ugyan feloldhatók, azonban a többes kriminalizációból ugyanazon cselekmény társadalomra veszélyességének eltérő jogalkotói megítélésére lehet következtetést vonni, ami nemcsak büntetőjog-dogmatikai, jogszabály-szerkesztési, hanem kriminálpolitikai szempontból is aggályosnak tekinthető.

\section{IRODALOMJEGYZÉK}

Ambrus István - Deák Zoltán (2011): Súlyponti kérdések a bankkártyával kapcsolatos bűncselekmények köréből. Belügyi Szemle, 59. évf. 2. sz. 85-103.

Balogh Ágnes (2007): A kísérlet és az elókészület, az önkéntes elállás, az önkéntes eredményelhárítás, felelősség a maradék-bűncselekmény miatt. In Balogh Ágnes - Kőhalmi László: Büntetőjog I. Általános rész. Budapest-Pécs, Dialóg Campus.

Belovics Ervin (2012a): A büncselekmény megvalósulási szakaszai. In Belovics Ervin et al. szerk.: Büntetőjog I. Általános Rész. A 2012. évi C. törvény alapján. Budapest, HVG-ORAC.

Belovics Ervin (2012b): Az egészséget veszélyeztető bűncselekmények - Btk. XVII. Fejezet. In Busch Béla szerk.: Büntetöjog II. Különös Rész. A 2012. évi C. törvény alapján. Budapest, HVG-ORAC.

Bursics Zoltán (1937): A magyar anyagi büntetőjog rövid összefoglalása. Budapest, Grill.

Brockhaus, Matthias (2006): Die strafrechtliche Dogmatik von Vorbereitung, Versuch und Rücktritt im europäischen Vergleich. Hamburg, Verlag Dr. Kovac.

Dávid Ferenc - Gál István László (2015): A terrorizmus büntetőjogi oldala: a terrorcselekmény és terrorizmus finanszírozása. Belügyi Szemle, 63. évf. 7-8. sz. 72-87.

Eser, Albin - Bosch, Nikolaus (2014): § 22. In Schönke, Adolf - Schröder, Horst Hrsg.: Strafgesetzbuch Kommentar. München, C.H. Beck.

Fayer László (1895): A magyar büntetöjog kézikönyve. Budapest, Franklin.

Fischer, Thomas (2008): Strafgesetzbuch und Nebengesetze. München, C.H. Beck.

Frank, Reinhard (1931): Das Strafgesetzbuch für das Deutsche Reich nebst dem Einführungsgesetz. 18. Aufl. Tübingen.

Gál István László (2017): Néhány gondolat a terrorizmus finanszírozása elleni büntetőjogi szabályozás hatékonyságáról. In Barabás A. Tünde - Vókó György szerk.: A bonis bona discere. Ünnepi kötet Belovics Ervin 60. születésnapja alkalmából. Budapest, Országos Kriminológiai Intézet. 49-59.

Gál István László (2013): A pénzmosás és a terrorizmus finanszírozása az új magyar büntetőjogban. Belügyi Szemle, 61. évf. 6. sz. 26-56.

Gál István László (2012): A pénzmosással és a terrorizmus finanszírozásával kapcsolatos jogszabályok magyarázata. Budapest, HVG-Orac.

Heller Erik (1931): A magyar büntetőjog tankönyve. Szeged, Szent István Társulat. 
Heil Fausztin (1911): Büntetőjogi Tanulmányok. Anyagi büntetőjog - Általános rész. Budapest, Jogállam Kiadóhivatala.

Hollán Miklós (2006): A büncselekmény közös elkövetésében való megállapodás a magyar büntetőjogban. Jogelméleti Szemle, 3. sz.

Hollán Miklós (2013): Stádiumok. In Kis Norbert szerk.: Büntetőjog I. Általános Rész. Alapismeretek a közigazgatási szakemberképzés számára. Budapest-Pécs, Dialóg Campus.

Jescheck, Hans-Heinrich - Weigend, Thomas (1996): Lehrbuch des Strafrechts. Allgemeiner Teil. 5. Auflage. Berlin, Dunckler\&Humblot.

Karsai Krisztina - Szomora Zsolt (2011): Anknüpfungspunkte für eine Vorverlagerung im ungarischen Strafgesetzbuch - Eine Bestandsaufnahme. In Sinn, Arndt et al. Hrsg.: Grenzen der Vorverlagerung in einem Tatstrafrecht. Eine rechtsverglichende Analyse am Beispiel des deutschen und ungarischen Strafrechts. Göttingen, V\&R Unipress.

Kónya István (2013): A büntetőjogi felelősség. In Kónya István szerk.: Magyar büntetőjog. Kommentár a gyakorlat számára. Budapest, HVG-ORAC.

Nagy Ferenc (2008): Stádiumok, elkövetők és szankciók (Gondolatok és reflexiók az új Btk. általános részi Tervezetéhez). Magyar Jog, 55. évf. 12. sz. 769-782.

Nagy Ferenc (2010): A magyar büntetôjog általános része. Budapest, HVG-ORAC.

Nagy Ferenc (2013): Régi és új tendenciák a büntetôjogban és a büntetőjog-tudományban. Budapest, Akadémiai Kiadó.

Puschke, Jens (2010): Grund und Grenzen des Gefährdungsstrafrechts am Beispiel der Vorbereitungsdeikte. In Hefendehl, Roland Hrsg.: Grenzenlose Vorverlagerung des Strafrechts?. Berlin, Berliner Wissenschafts-Verlag.

Szomora, Zsolt (2011): Die ungarische Versuchsdogmatik. In Sinn, Arndt - Gropp, Walter - Nagy, Ferenc Hrsg.: Grenzen der Vorverlagerung in einem Tatstrafrecht. V \& R Unipress, Osnabrück.

Tokaji Géza (1984): A büncselekménytan alapjai a magyar büntetőjogban. Budapest, KJK.

Roxin, Claus (2003): Strafrecht Allgemeiner Teil. Band II. München, C.H. Beck.

Sinn, Arndt (2011): Vorverlagerung der Strafbarkeit - Begriff, Ursachen und Regelungstechniken. In Sinn, Arndt - Gropp, Walter - Nagy, Ferenc Hrsg.: Grenzen der Vorverlagerung in einem Tatstrafrecht. Göttingen, V\&R Unipress.

Váradi Erika (2012): A bủncselekmény megvalósulási szakaszai (stádiumtan). In Horváth Tibor - Lévay Miklós szerk.: Magyar büntetőjog. Általános Rész. Budapest, Complex.

Varga Zoltán (2004): 303. §. In Jakucs Tamás szerk.: A Büntető Törvénykönyv magyarázata. Budapest, KJK-Kerszöv.

Varga Zoltán (2009): 303. §. In Varga Zoltán szerk.: A Büntetö Törvénykönyv magyarázata. Budapest, KJK-Kerszöv.

Vida Mihály (2013): Az egészséget veszélyeztető bűncselekmények. (Btk. XVII. fejezet) In Karsai Krisztina szerk.: Anyagi büntetőjog. Különös rész I. Szeged, Iusrisperitus.

Wessels, Johannes - Werner, Beulke (2012): Strafrecht. Allgemeiner Teil. 42. Aufl. Heidelberg, C. F. Müller.

Wlassics Gyula (1887): A bünkísérlet és bevégzett büncselekmény. A tettesség és a részesség tana. II. kötet. Budapest, Magyar Tudományos Akadémia.

Wlassics Gyula (1914): A kísérlet és a részesség köréből. In Büntetőjogi dolgozatok. Balogh Jenő születése ötvenedik évfordulójának ünnepére. Pécs, Wessely és Horváth Könyvnyomda.

Zaczyk, Rainer (2010): § 22. In Kindhäuser, Urs - Neumann, Ulfrid - Paeffgen, Hans-Ullrich Hrsg.: Strafgesetzbuch. Band 1. Baden-Baden, Nomos. 


\title{
ABSTRACT
}

\section{The Regulation of Preparation of Crime in Hungary}

\author{
GÁL Andor
}

The Criminal Code uses several legal forms to punish preparatory conducts, therefore the legislation is complex. This paper has the aim to present these legal solutions in detail. Because of the overregulation of the preparatory actions, there are more sui generis preparatory criminal offences, which have a collision with other criminal offences (concurrent punishability). Thus, this paper has also the aim to present the phenomenon of 'overregulating' in the field of preliminary stages of criminal offences.

Keywords: attempt, extension of criminal liability, overregulation, preparation, sui generis punishability 